\title{
DESCRIPTIVE ANALYSIS OF EMPLOYMENT IN AZERBAIJAN: POSSIBILITIES OF THE DUTCH DISEASE
}

\section{Ibrahim Niftiyev ${ }^{1,2,3}$}

${ }^{1} \mathrm{Ph} . \mathrm{D}$. candidate, Institute of Finance and International Economic Relations, Doctoral School in Economics, University of Szeged, Szeged, Hungary. Email: ibrahimniftiyev@gmail.com

${ }^{2}$ Researcher, European Economy Research Center, Azerbaijan State University of Economics (UNEC), Baku, Azerbaijan.

${ }^{3}$ Lecturer, International School of Economics (ISE), Azerbaijan State University of Economics (UNEC), Baku, Azerbaijan.

Received 27 December 2019; accepted 29 May 2020; published online 10 July 2020

\begin{abstract}
:
This paper conducts a descriptive statistical analysis of employment in Azerbaijan covering the period between 2000 and 2018 to study the effects of the Dutch disease hypothesis. Azerbaijan has been a research subject of the Dutch disease due to the boom in the oil sector since independence from the Soviet Union. This paper bases its analysis on the descriptive statistics of employed persons per sector, its year on year growth dynamics, and cumulative growth rates. The results indicate that there are developments in employment that are in line with the spending effect of the Dutch disease model, as during the given time period, the mining sector did not experience sky-high employment, and manufacturing and agriculture shrank, though services increased their role. Moreover, constructed scatterplot matrix and conducted Pearson's R correlation analysis shed light on the sectoral relationships among the critical economic variables like real effective exchange rate, oil prices, oil GDP, non-oil GDP, oil exports, and transfers from the sovereign wealth fund (SOFAZ), etc. However, the conclusions should be drawn with a significant extension of caution, as the descriptive investigation is extremely limited in terms of the identification of causal relationships.
\end{abstract}

Keywords: Dutch disease, Azerbaijan economy, sectoral employment, descriptive statistics

JEL Classification: F41, F43, Q33

\section{INTRODUCTION}

The economy of Azerbaijan has been analyzed according to the Dutch disease theory on a number of occasions due to increased oil production and exports, the nature of economic 
growth, chronic Real Effective exchange Rate (REER) appreciation, and rapid spending over the period of oil booming since independence from the Soviet Union (Hasanov, 2011; 2013; Hasanov and Samadova, 2010; Hasanov and Hasanli, 2011). The three-sector economy that the core model of the Dutch disease describes is comprised of a booming $\left(\mathrm{S}_{\mathrm{B}}\right)$, lagging $\left(\mathrm{S}_{\mathrm{L}}\right)$, and non-tradable $\left(\mathrm{S}_{\mathrm{NT}}\right)$ sector. An assumption is that $\mathrm{S}_{\mathrm{B}}$ and $\mathrm{S}_{\mathrm{L}}$ produce tradable goods, while $S_{\mathrm{NT}}$ contains tertiary sectors that are non-tradable. In the tertiary sectors, output is produced by the exclusive production factors for each sector, the prices for the ready products are set internationally, the factor prices are flexible but internationally immobile, and labor is mobile and moves between sectors to equalize wages (Corden and Neary, 1982; Corden, 1984).

As Corden (1984) summarizes, the source of a boom can be a once-for-all exogenous technical improvement, such as a windfall discovery of a new resource and an exogenous rise in the prices of the products of $S_{B}$. There are two effects of Dutch disease: the resource movement effect and the spending effect. The spending effect occurs when revenue accumulated from taxes is spent by the government. This, under the positive income elasticity of demand, provides additional incentives to employ more in tertiary sectors due to the increased demand for services. In such cases, the labor force moves from $S_{B}$ and $S_{L}$ into $S_{N T}$. If increased marginal productivity resulting from a boom in a small and open economy results in the labor force moving out of lagging sectors and into booming sectors, a resource movement effect occurs. This increases the demand for labor in non-booming (or lagging) sectors and lowers their output. This is called direct de-industrialization, and an appreciation of REER does not occur.

The second form of the resource movement occurs when there is a movement of labor from $S_{N T}$ into $S_{B}$, along with labor movement from $S_{L}$ into $S_{N T}$ (which results from the spending effect). The second form of the resource movement effect is also called "indirect de-industrialization". Usually, booming sectors are mineral sectors or corps, while lagging industries such as manufacturing or agriculture are lagging sectors.

Several resource-rich countries like Australia (Corden, 2012), Nigeria (Otaha, 2012), Indonesia (Pangestu, 1990), Mexico (Auty, 1991), Colombia (Kamas, 1986, as cited in Bature, 2013), Norway, the Netherlands, the United Kingdom (Hutchison, 1994), and Kazakhstan (Akhmetov, 2015) have been considered "Dutch disease-infected" as they possess certain common characteristics, such as having a booming sector, an undiversified economy (or having numerous lagging sectors), contracted manufacturing sectors, and real exchange rate appreciation.

In the case of Azerbaijan, technical improvements beginning in 1994 as a result of major foreign directed investments (FDI) upgraded the production frontier of the 
economy in terms of the mining sector and gradually increased oil prices, which caused the economy to boom. The most frequently observed symptoms of Dutch disease in this case were the increased role of the mining sector and the simultaneous decreased share of manufacturing and agriculture, REER appreciation, higher output, and employment in services due to the spending effect. However, generally, the resource movement effect is very low or absent when the booming sector is capital-intensive rather than labor-intensive. In fact, extractive industries, particularly the oil and gas sector, are capital-intensive. That is why the resource movement effect is not anticipated in the case of Azerbaijan, at least in its direct deindustrialization form. Hasanov (2013) also discusses the actuality of spending effect in the economy of Azerbaijan, rather than the resource movement effect.

So far, several studies focused on the booming and diversification aspects of the Azerbaijan economy. Boom and bust cycles alongside with the competitive nature of the national economy, provide all necessary starting points to conceptualize the primary rationale of the Dutch disease in the Azerbaijan economy. For instance, Musayev (2019) outlined that Azerbaijan's economic growth was higher than the indicator of balanced growth during the oil era but lower during the post-oil period. The commodity crisis of 2014-2015 decreased economic growth in Azerbaijan. Bayramov (2016) emphasized new opportunities that were emerged in 2015 to diversify the national economy in Azerbaijan, which overlaps with the critical concept of turning crises to opportunities.

All in all, specific policy implications and the experience of the other oil-rich countries should be considered in the Azerbaijani case as well. Babayev (2019) argued that, based on the case of the United Arab Emirates (UAE), Azerbaijan might benefit from the policy decisions of the UAE even if the outcomes might occur in different magnitude. This will increase economic opportunities and decrease current and potential monopolistic trends in the economy of Azerbaijan to boost economic growth (Hajiyev, 2013).

Statistical data regarding the economy of Azerbaijan displays certain symptoms that the Dutch disease model indicates. Figure 1 shows how the mining sector assumed a major role in the economy until 2013, reaching a peak in 2007 at $56.3 \%$ and becoming a booming sector; however, services replaced the mining sector following rapid growth between 2013 and 2017, comprising 46.5\% on average share per annum. Other economic activities like manufacturing and agriculture never exceeded an upper bound of $10 \%$ in a 12-year timescale. Figure 2 indicates that during the high oil price levels, the GDP growth rate also rose, leading to rapid foreign currency inflow and exchange rate appreciation. In fact, on the edge of oil booming (2008-2011) GDP growth rate was 34.5\%, but it collapsed after the global financial crises in 2009 and commodity price slumps in 2014-2015. 
Figure 1: Decomposition of real GDP, in \%.

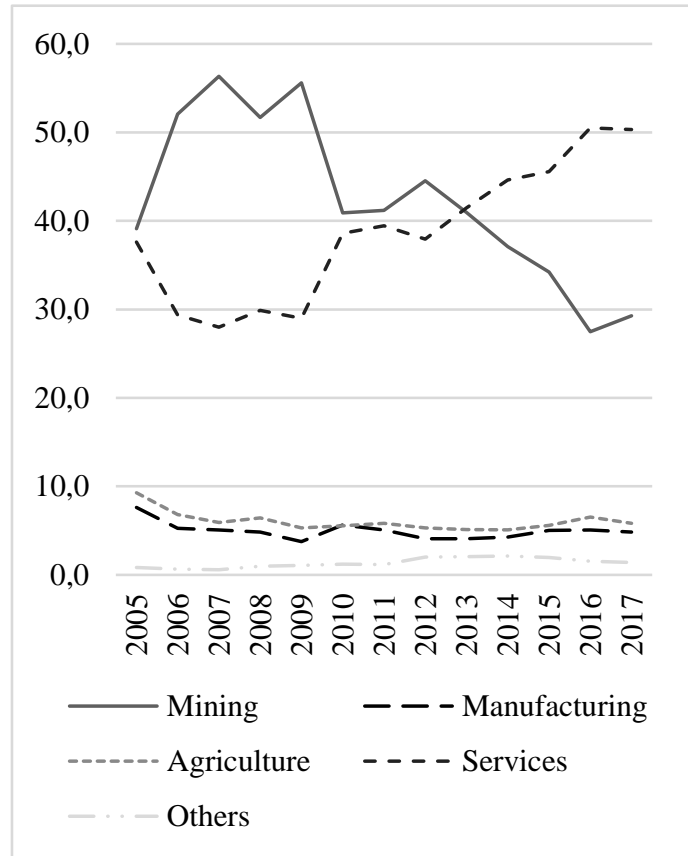

Source: SSCRA, author's calculations.
Figure 2: GDP growth rates, in \% (right axis) and oil prices, in USD per barrel, BRENT trademark (left axis).

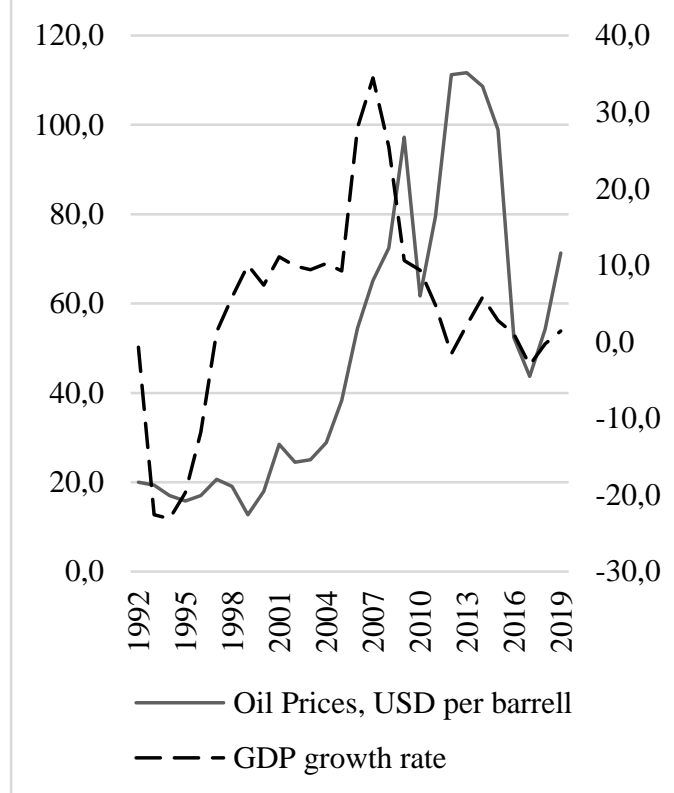

Source: World Bank national accounts data, OECD National Accounts data files, and BP Statistical Review of World Energy.

Oil booming was accompanied by REER appreciation and extremely high shares of mineral products in the total exports (more than $80 \%$ in 2008-2018 period; see Fig. 3). Overvaluation of the national currency made non-booming sectors less competitive, pushing down the output of the manufacturing sector compared to the mining sector, as shown in Figure 4, where the ratio is higher than 1 starting from 2006. Figure 4 also depicts via the data related to current account balance being a share of GDP. In fact, oil booming boosted the trade balance in favor of a surplus; however, it began to slow from 2014-2015. Consequently, the rapid economic progress decelerated after the sharp commodity price downturn, signaling the unreliable nature of commodity exports compared to value-added manufacturing exports. This aligns with the general framework of the Dutch disease model.

Considering the previously discussed aspects of the Dutch disease theory and the trends in the economy of Azerbaijan, the main research question of this study is formulated as follows: is the distribution of the statistical data in employment covering the period between 2000-2018 consistent with the Dutch disease hypotheses? To answer this question, a descriptive analysis is carried out to observe the statistical properties of employment data in the mining, manufacturing, agriculture and services sectors. These data are compared with features of the original model presented by Corden and Neary (1982) and Corden (1984). 
The next section of the paper outlines the sources of the data, methods and main variables employed. The third section presents the results. The fourth and the fifth sections provide a discussion and conclusion, respectively, and argue for the need for further studies on the Dutch disease phenomenon in the economy of Azerbaijan.

Figure 3: Real Effective Exchange Rate $(1997=100 \%)$ and Mineral Exports, \% of total exports.

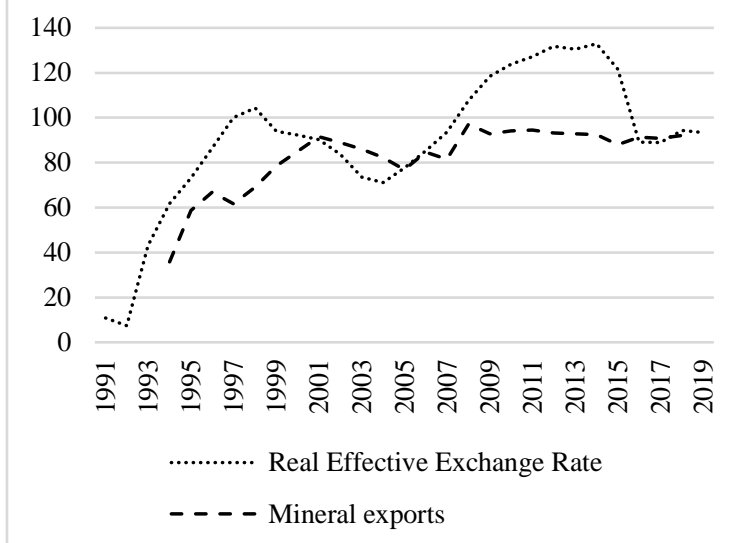

Source: Islamic Development Bank, SSCRA and author's own calculations
Figure 4: Current Account Balance (\% of GDP) and the ratio of mining output over the manufacturing output

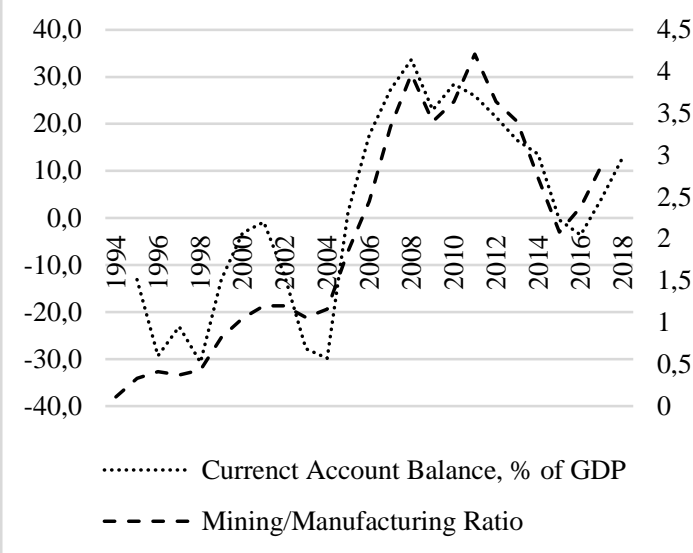

Source: World Bank, SSCRA and author's own calculations

\section{DATA AND METHODS}

To analyze the effects of the so-called Dutch disease in terms of employment in Azerbaijan, data provided by the State Statistical Committee of the Republic of Azerbaijan (SSCRA) from 2000-2018 is utilized. Also, the data from Central Bank of the Republic of Azerbaijan (CBAR), British Petroleum (BP), reports of State Oil Fund of Azerbaijan (SOFAZ), Islamic Development Bank, and World Bank have been operationalized. The data range is between 2000 and 2018, which excludes the 1990s due to the many outliers that decreased the reliability of the outcomes of the analysis.

The sectors analyzed include mining, manufacturing, agriculture, and services. The data are based on the numbers of employees in the economy. The mining sector mainly consists of the oil and gas sectors, while manufacturing refers to the production of processed raw materials, and the agriculture sector encompasses forestry and fishery employment data. Services consist of construction, trade and repair services, financial and insurance activities, transportation and storage, public administration and defense, education, real estate services, and others. 
The main elements of the applied descriptive statistical analysis are the minimum value, maximum value, range, mean, median, mode, standard deviation, variance, coefficient of variation, skewness, and kurtosis values. The descriptive analysis is performed on three levels: natural value, which is a thousand persons per sector; year on year growth; and cumulative growth, both being in percentage points. As a concluding part of the results section scatterplot matrix and Pearson's R correlation analysis have been added to check the correlation between the pre-selected economic sectors and real effective exchange rate (REER is an essential economic indicator among the Dutch disease studies, so the analysis provides initial conceptualization of the hypothesis).

\section{RESULTS}

Table 1 summarizes the descriptive analysis of employment in Azerbaijan between 2000-2018 in the mining, manufacturing, agriculture, and services sectors in terms of employed persons (left-hand side) and year on year percentage changes (right-hand side). The expected outcome of recent trends in the economy of Azerbaijan that align with the Dutch disease model is that manufacturing and agriculture would shrink, while mining and services would expand alongside REER appreciation, output, and trade booming in the mineral sectors. Accordingly, the mining sector had the lowest range (7.30 thousand persons, standard deviation -2.72 thousand persons, coefficient of variation - 0.07). Thus, the mining employment data did not denote any extreme positive skewness (0.33) and the kurtosis value (-1.69), which indicates that mining did not experience any significant employment decrease or increase. This points to the fact that resource movement in its "direct de-industrialization" form is not observable in the Azerbaijan economy.

Meanwhile, Table 1 shows the highest range in services by 392.80 thousand persons alongside its positive linear increase over time (see. Fig. 5), which indicates the "indirect de-industrialization" form of resource movement. With 14 years of uprising against five years' decrease, services have a coefficient of variation by 0.11 , reaching a maximum amount of labor of 1288.60 thousand persons from 895.80 thousand. The negative skewness $(-0.44)$ and negative kurtosis $(-1.04)$ of services reveal that the stable and upward increase in the employment of services was in fact accompanied by the booming period, suggesting an indirect de-industrialization of the resource movement effect.

The manufacturing and agriculture sectors with the same increased (9) and decreased years (10) possessed the highest coefficient of variations of 0.11 and 0.24 , respectively, pointing to higher spread data distribution, as well as volatile developments. The range was higher in manufacturing (58.40) than in agriculture (53.60), indicating the decreased share of agriculture in employment. Comparing the timely progress in Figure 
5 of these two sectors to the positive and high skewness values for the previously mentioned sectors, it can be argued that these sectors had lower shares during the postboom era compared to the pre-booming period. High positive kurtosis values can be understood with reference to the fact that, in the 1990s and early 2000s, the national currency was overvalued and competitiveness had been lost, leading to a decrease in the employment, and output level. For this reason, relatively high levels of employment in these sectors are not observed during recent years.

Table 1: Descriptive statistics of employment in economic sectors, 2000-2018.

\begin{tabular}{|c|c|c|c|c|c|c|c|c|c|}
\hline & \multicolumn{4}{|c|}{ In thousand persons } & & \multicolumn{4}{|c|}{ In year on year \% } \\
\hline & 咅 & 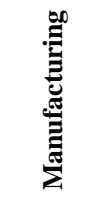 & 总 & 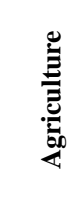 & & 意 & 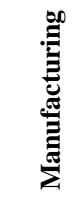 & 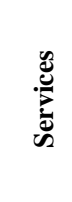 & 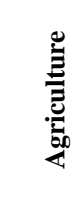 \\
\hline $\begin{array}{c}\begin{array}{c}\text { Observation } \\
\text { number (n) }\end{array} \\
\end{array}$ & 19 & 19 & 19 & 19 & $\begin{array}{c}\text { Observation } \\
\text { number (n) }\end{array}$ & 18 & 18 & 18 & 18 \\
\hline Min & 33.70 & 84.80 & 895.80 & 36.40 & Min & -12.63 & -23.39 & -0.41 & -34.29 \\
\hline Max & 41.00 & 143.20 & 1288.60 & 90.00 & Max & 11.36 & 9.79 & 7.16 & 25.55 \\
\hline Range & -7.30 & -58.40 & -392.80 & -53.60 & Range & -23.99 & -33.18 & -7.57 & -59.84 \\
\hline Mean & 36.91 & 103.56 & 1140.72 & 48.19 & Mean & -0.67 & -1.13 & 2.06 & -2.17 \\
\hline Mode & 35.50 & N/A & N/A & N/A & Mode & $\# \mathrm{~N} / \mathrm{A}$ & \#N/A & \#N/A & \#N/A \\
\hline Median & 35.50 & 102.90 & 1157.20 & 45.30 & Median & -0.27 & 0.19 & 1.53 & 1.66 \\
\hline $\begin{array}{l}\text { Standard } \\
\text { Deviation } \\
\end{array}$ & 2.72 & 11.81 & 128.54 & 11.71 & $\begin{array}{l}\text { Standard } \\
\text { Deviation } \\
\end{array}$ & 5.71 & 8.55 & 2.13 & 13.05 \\
\hline Variance & 7.38 & 139.40 & 16522.63 & 137.15 & Variance & 32.63 & 73.12 & 4.55 & 170.35 \\
\hline $\begin{array}{c}\text { Coefficient } \\
\text { of Variation }\end{array}$ & 0.07 & 0.11 & 0.11 & 0.24 & $\begin{array}{c}\text { Coefficient } \\
\text { of Variation }\end{array}$ & -8.52 & -7.59 & 1.03 & -6.03 \\
\hline Skewness & 0.33 & 2.01 & -0.44 & 2.94 & Skewness & -0.13 & -1.04 & 0.87 & -0.85 \\
\hline Kurtosis & -1.69 & 6.93 & -1.04 & 9.58 & Kurtosis & 1.46 & 1.09 & 0.27 & 2.35 \\
\hline
\end{tabular}

Source: SSCRA and author's own calculations.

In year on year growth rate terms (the right-hand side of Table 1), the highest and the only positive mean value was in services (2.06) while agriculture suffered a 2.17 growth rate between 2000-2018. The mean value for manufacturing growth (1.13) was higher than mining (-0.67). The descriptive statistical analysis shows that services was the only sector that had positive skewness, while the negative skewness of mining, manufacturing, and agriculture indicated their higher levels from the preboom and late 1990s. The lower kurtosis values for manufacturing and services can be interpreted as their relatively normal distribution around the mean, while mining and agriculture had volatile growth rates over the period. 
Table 2: Descriptive statistics of the employees throughout the economy, 2000-2018

\begin{tabular}{|c|c|c|c|c|}
\hline & \multicolumn{4}{|c|}{ In cumulative $\%, 2000$ year being $100 \%$} \\
\hline & $\stackrel{\infty}{\stackrel{D}{\Xi}}$ & 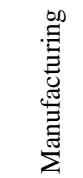 & 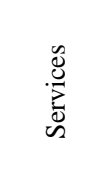 & 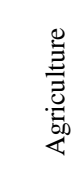 \\
\hline $\begin{array}{l}\text { Observation } \\
\text { number (n) }\end{array}$ & 18 & 18 & 18 & 18 \\
\hline Min & 86.74 & 53.10 & 105.37 & 23.18 \\
\hline Max & 105.00 & 79.71 & 137.10 & 73.56 \\
\hline Range & -18.25 & -26.61 & -31.73 & -50.37 \\
\hline Mean & 94.36 & 70.36 & 125.35 & 47.32 \\
\hline Mode & 96.69 & \#N/A & \#N/A & \#N/A \\
\hline Median & 91.60 & 72.51 & 126.46 & 47.94 \\
\hline $\begin{array}{c}\text { Standard } \\
\text { Deviation }\end{array}$ & 6.94 & 6.97 & 10.65 & 10.66 \\
\hline Variance & 48.13 & 48.59 & 113.35 & 113.53 \\
\hline $\begin{array}{l}\text { Coefficient } \\
\text { of Variation }\end{array}$ & 0.07 & 0.10 & 0.08 & 0.23 \\
\hline Skewness & 0.41 & -0.82 & -0.53 & 0.30 \\
\hline Kurtosis & -1.64 & 0.48 & -0.96 & 2.10 \\
\hline
\end{tabular}

Source: Author's calculations based on the SSCRA data.
Figure 5: Distribution of the employees across the economic sectors, thsd. persons, 2000-2018

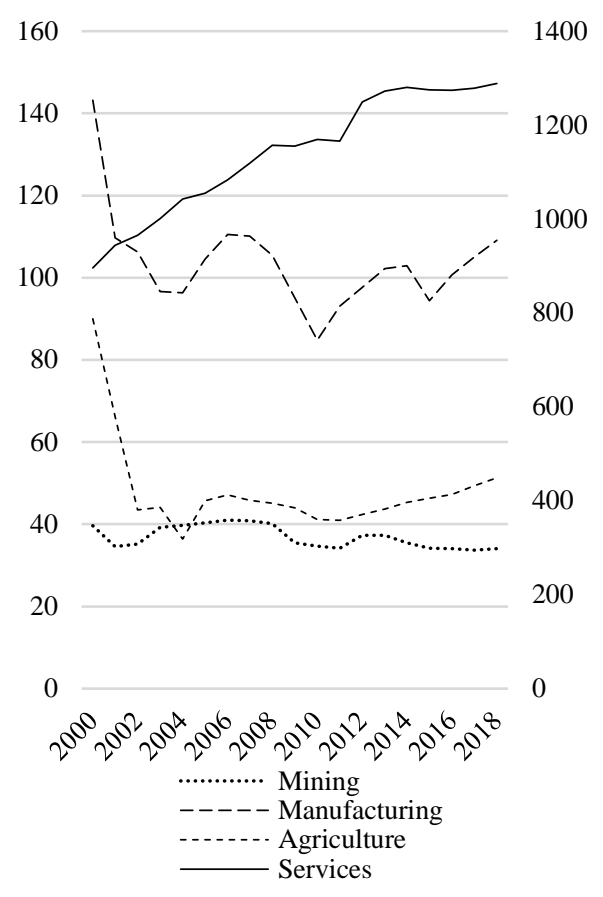

Source: SSCRA, author's own calculations

Table 2 shows the results of the descriptive statistical analysis of the cumulative growth rates $(2000=100 \%)$. Similarly, the highest range was in agriculture and services, while mining showed the lowest one. Compared to the worst performer, which was agriculture (47.32), the mean cumulative growth rate was $125.35 \%$ in services. The variability of the cumulative growth was the highest in agriculture $(0.23$, measured by the coefficient of variation) and manufacturing (0.10), while mining and services shared close values (0.07 and 0.08, respectively). Compared to the year on year growth rate dynamics, the skewness in the cumulative growth rate indicates that services had a negative value (-0.53). Lower kurtosis values could be observed in mining and services, while manufacturing and agriculture had positive values.

Furthermore, Figure 6 demonstrates the extension of the linear relationship between REER and employment in economic sectors. REER was negatively correlated with mining, manufacturing, and agriculture employment but positively associated with the services sector. On the diagonal of Figure 6, the distribution of the data (according to the position on the Y-axis) have been described. REER has a normal distribution, while other variables have a skewed shape. Thus, the negative slope for the relationship between REER and mining indicates the absence of direct deindustrialization of the resource movement effect of Dutch disease. However, the 
negative connection between REER and manufacturing and agriculture, but the positive association between REER and services might point to the presence of indirect de-industrialization, as well as spending effect of the theory.

Figure 6: Correlation between employment and REER in Azerbaijan, 2000-2018

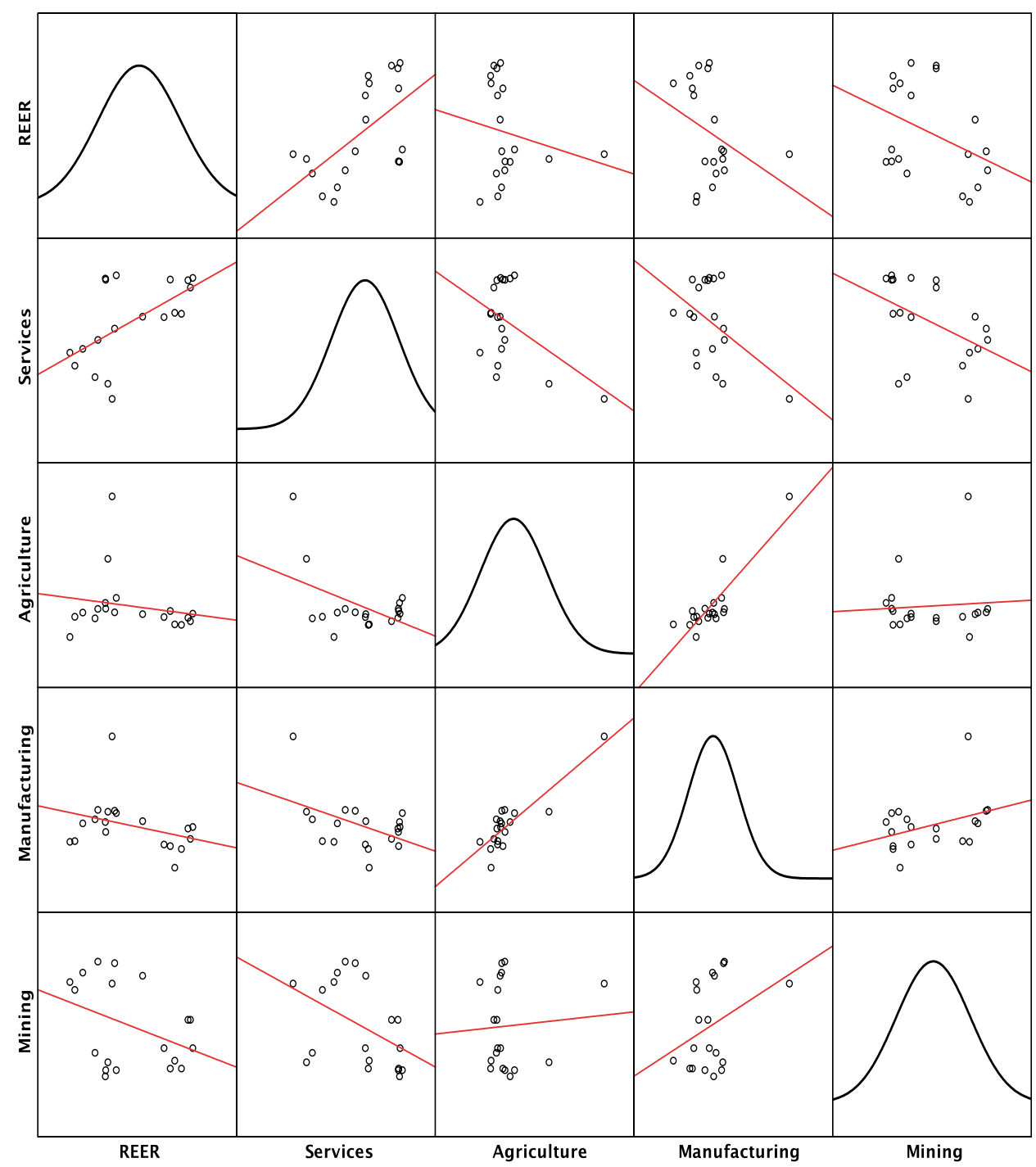

Source: Own construction based on the SSCRA and Islamic Bank of Development.

Notes: 1) To put simply, the first column of the scatter matrix denotes the relationship where REER is on the $\mathrm{X}$-axis and where the Y-axis contains mining, manufacturing, agriculture, and services employment data. Similar logic can be followed to understand other parts of the scatter plot matrix; 2) The sample size is 19 for all variables; 3 ) $R^{2}$ for REER and mining is $0.15, R^{2}$ for REER, and services is $0.35, \mathrm{R}^{2}$ for REER, and manufacturing is $0.11, \mathrm{R}^{2}$ for REER and agriculture is 0.034 . 
Lastly, making an accurate judgment of the spending effect of Dutch disease in the case of Azerbaijan is relatively challenging because of the multiple reasons behind the indicated dynamics. However, the original theory and the established body of the literature shed light on specific paths of the existence of the spending effect. Subsequently, a more genuine relationship can be derived from the correlation matrix that relays on the variables that are very commonly used in Dutch disease research. From Table 3, a strong positive relationship can be observed between REER and spending of the government and expenditure of SOFAZ, which can be in line with spending effect (.83 and .93 respectively). The other results include the positive and significant connection between oil prices and oil GDP (.67), a positive and meaningful relationship between non-oil GDP and share of SOFAZ in the state budget (.87). As crude oil exports increased, the share from SOFAZ also made progress having more shares in the state budget (.81). Natural gas exports had a positive and vital impact on the non-oil GDP and the percentage share of SOFAZ handovers in the state budget (.93). Non-oil GDP widely includes services, so the revenue sourced from it also was spent inside the government expenditures.

Table 3:Correlation Matrix (Pearson's R) for the selected variables, time range:2003-2018.

\begin{tabular}{|c|l|c|c|c|c|c|c|c|c|c|c|c|}
\hline & & 1 & 2 & 3 & 4 & 5 & 6 & 7 & 8 & 9 & 10 & 11 \\
\hline 1 & $\begin{array}{l}\text { REER } \\
(2010=100)\end{array}$ & 1 & & & & & & & & & & \\
\hline 2 & Oil Price & $.83^{* *}$ & 1 & & & & & & & & & \\
\hline 3 & Oil GDP & $.63^{* *}$ & $.67^{* *}$ & 1 & & & & & & & & \\
\hline 4 & Non-oil GDP & .44 & .27 & $.80^{* *}$ & 1 & & & & & & & \\
\hline 5 & $\begin{array}{l}\text { Crude Oil } \\
\text { Exports }\end{array}$ & $.76^{* *}$ & $.60^{*}$ & $.79^{* *}$ & $.57^{*}$ & 1 & & & & & & \\
\hline 6 & $\begin{array}{l}\text { Natural Gas } \\
\text { Exports }\end{array}$ & .17 & 0 & $.65^{*}$ & $.93^{* *}$ & .01 & 1 & & & & & \\
\hline 7 & $\begin{array}{l}\text { Government } \\
\text { Expenditure }\end{array}$ & $.83^{* *}$ & $.60^{*}$ & $.65^{* *}$ & $.69^{* *}$ & $.70^{* *}$ & $.56^{*}$ & 1 & & & & \\
\hline 8 & $\begin{array}{l}\text { Expenditures of } \\
\text { SOFAZ }\end{array}$ & $.93^{* *}$ & $.79^{* *}$ & $.73^{* *}$ & $.62^{*}$ & $.75^{* *}$ & .48 & $.93^{* *}$ & 1 & & & \\
\hline 9 & $\begin{array}{l}\text { Revenue of } \\
\text { SOFAZ }\end{array}$ & $.80^{* *}$ & $.70^{* *}$ & $.78^{* *}$ & $.62^{*}$ & $.76^{* *}$ & .47 & $.78^{* *}$ & $.87^{* *}$ & 1 & & \\
\hline 10 & $\begin{array}{l}\text { Transfers from } \\
\text { SOFAZ }\end{array}$ & $.83^{* *}$ & $.65^{* *}$ & $.82^{* *}$ & $.75^{* *}$ & $.81^{* *}$ & $.66^{*}$ & $.90^{* *}$ & $.94^{* *}$ & $.89^{* *}$ & 1 & \\
\hline 11 & $\begin{array}{l}\text { SOFAZ } \\
\text { transfers as } \% \\
\text { of the state } \\
\text { budget }\end{array}$ & $.72^{* *}$ & $.60^{*}$ & $.84^{* *}$ & $.87^{* *}$ & $.66^{* *}$ & $.84^{*}$ & $.87^{* *}$ & $.88^{* *}$ & $.77^{* *}$ & $.94^{* *}$ & 1 \\
\hline & $\begin{array}{l}* * \text { Correlation is significant at the } 0.01 \text { level }(2 \text {-tailed). } \\
* \text { Correlation is significant at the } 0.05 \text { level (2 tailed). }\end{array}$ & & & & & \\
\hline
\end{tabular}

Source: SSCRA, CBAR, Reports of SOFAZ, IndexMundi, author's calculations.

Note: Observation number is 16 for all variables except Natural Gas Exports $(\mathrm{N}=13)$ 


\section{DISCUSSION}

A descriptive statistical analysis of employment data alone does not provide the full picture of the Dutch disease theory; however, it is a useful means to begin to conceptualize its presence. To clarify the causal relationship between the booming and lagging sectors, a model approach with more precise diagnostic adjustments is necessary. Moreover, real wage and output data should be linked together to paint a more detailed picture. Accordingly, future research related to Dutch disease in Azerbaijan should employ econometric investigations alongside meta-structural approaches, such as the resource curse hypothesis and institutional evaluations. Deconstructing the non-tradable sectors and proper classification from the point of exports and imports could shed more light on the effects of Dutch disease in Azerbaijan. As Corden (1984) indicates, not every tradeable product is exported by the country. In the background of booming and lagging sectors, the Dutch disease can be easily misunderstood if highly aggregated data is used. Thereby, correlation analysis is a weak estimation of the power and significance between the selected variables (also can be seen from the low $\mathrm{R}^{2}$ values, which indicates to use alternative approaches). Without a sub-sectoral analysis of output and international trade, it is difficult to conclude the existence of the Dutch disease hypotheses in an economy.

\section{CONCLUDING REMARKS}

This paper investigated the descriptive properties of the statistical data regarding employment in Azerbaijan within a Dutch disease framework. The research question adopted was as follows: is the distribution of the statistical data in employment covering the period between 2000-2018 consistent with the Dutch disease hypotheses? The main results of statistical analysis analyzed the presence of the phenomenon, including REER appreciation, high shares in the booming sector in the output, and exports, while manufacturing and agriculture as lagers contracted their share. The results indicated that the resource movement effect of the Dutch disease could not be observed in mining employment, because, being a capital-intensive sector, it did not experience any extraordinary employment levels. On the contrary, it decreased over the time period examined. However, the negative growth rates of the non-oil tradable sectors and the rapid increase in services employment fit the spending effect of the Dutch disease model. While the scatter plot matrix demonstrated a positive relationship between REER and mining, manufacturing and agriculture, and negative relationship between REER and services, Pearson's R correlation identified a strong, positive and significant connection between the variables that support the Dutch disease effects. However, on a descriptive level, this investigation should be treated illustrative rather than conclusive. 


\section{REFERENCES}

Akhmetov, A. (2017), Testing the presence of the Dutch disease in Kazakhstan, Munich Personal RePEc Archive (MPRA) Paper 77936.

Auty, R. (2001), Reforming resource-abundant transition economies: Kazakhstan and Uzbekistan. In Auty R. (Eds.): Resource Abundance and Economic Development, Oxford University Press: New York, 260-276.

Babayev, B. (2019). Studying The Case of The UAE in Economic Diversification and Non-Oil Export Growth: Public Policy Lessons for Azerbaijan. Journal of Economic Sciences: Theory \& Practice, 76(2), 46-55.

Bature, B. N. (2013), The Dutch Disease and the Diversification of an Economy: Some Case Studies, IOSR Journal of Humanities and Social Sciences, 15(5), 6-14.

Bayramov, V. (2016), Azerbaijan Economy in 2015: New Opportunities for Further Diversification. Journal of Economic Sciences: Theory \& Practice, 73(1), 45-51.

British Petroleum Company (2018) BP statistical review of world energy. https://www.bp.com/content/dam/bp/en/corporate/pdf/energy-economics/statistical -review/bp-stats-review-2018-full-report.pdf, Accessed: December 13, 2019.

Corden, W. M., and Neary, J. P. (1982), Booming sector and de-industrialization in a small open economy. The economic journal, 92(368), 825-848.

Corden, W. M. (1984), Booming sector and Dutch disease economics: survey and consolidation. Oxford economic Papers, 36(3), 359-380.

Corden, W. M. (2012), Dutch disease in Australia: policy options for a three- speed economy. Australian Economic Review, 45(3), 290-304.

Islamic Development Bank, (2019), World Bank - Development Indicators (WDI) 2017, Retrieved from http://data.isdb.org/pxfdrcg/world-bank-developmentindicators-wdi-2017-idb-aggregates?tsId=1005720,Accessed:December 30, 2019.

Hajiyev, N. (2013), Assessment Stages of Cyclical Development of Monopoly and Competition in Terms of the Reconstruction of Azerbaijan Economy. Journal of Economic Sciences: Theory \& Practice, 70(1), 97-117.

Hasanov, F., and Samadova, I. (2010), The Impact of Real Effective Exchange Rate on the Non-oil Export: The Case of Azerbaijan. MPRA Paper, University Library of Munich, Germany.

Hasanov, F. (2011), Analyzing price level in a booming economy: the case of Azerbaijan. Economics Educational and Research Concortium, Working Paper, (11/02E).

Hasanov, F., and Hasanli, K. (2011), Why had the Money Market Approach been irrelevant in explaining inflation in Azerbaijan during the rapid economic growth period. Middle East. Financ. Econ, 10, 1-11. 
Hasanov, F. (2013), Dutch disease and the Azerbaijan economy. Communist and Post-Communist Studies, 46(4), 463-480.

Hutchison, M. M. (1994), Manufacturing sector resiliency to energy booms: empirical evidence from Norway, the Netherlands, and the United Kingdom, Oxford Economic Papers, 46, 311-329.

Kamas, L. (1986), Dutch disease economics and the Colombian export boom, World Development, 14(9), 1177-1198.

Musayev, T. (2019), The oil boom in Azerbaijan and modeling of economic growth in post-oil era, Journal of Economic Sciences: Theory \& Practice, 76(2), 31-45.

Otaha, J. I. (2012), Dutch disease and Nigeria oil economy, African Research Review, 6(1), 82- 90.

Pangestu, M. (1990), Adjustment problems of a small oil-exporting country: Did Indonesia Suffer from the Dutch Disease?, Economic Development in East and Southeast Asia: Essays in Honor of Professor Shinichi Ichimura, Institute of Southeast Asian Studies, 121-137.

State Statistical Committee of the Republic of Azerbaijan (SSCRA) (2019), Retrieved from https://www.stat.gov.az/source/labour/en/002_6-7en.xls, Accessed: December 12 2019)

The World Bank, (2019), Retrieved from https://data.worldbank.org/, Accessed: January 252020. 